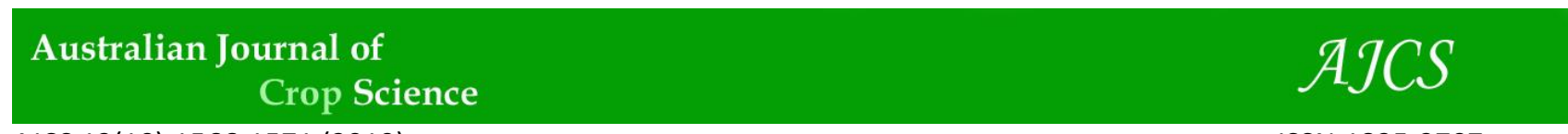

AJCS 13(10):1566-1571 (2019)

ISSN:1835-2707

doi: 10.21475/ajcs.19.13.10.p1316

\title{
Effects of organomineral fertilizers formulated with biosolids and filter cake on common bean yield crop (Phaseolus vulgaris L.)
}

\author{
Hellen Cristina da Silva ${ }^{1}$, Luara Cristina de Lima ${ }^{1}{ }^{*}$, Reginaldo de Camargo ${ }^{1}$, Regina Maria Quintão Lana ${ }^{1}$, \\ Ernane Miranda Lemes ${ }^{1}$, Atalita Francis Cardoso ${ }^{2}$
}

\author{
${ }^{1}$ Institute of Agricultural Science (ICIAG), Federal University of Uberlândia (UFU), Brazil \\ ${ }^{2}$ University Center of Goiatuba (UNICERRADO), Brazil
}

*Corresponding author: lima_luara@yahoo.com.br

\begin{abstract}
The objective of this research was to evaluate the efficiency of different sources of residues in the composition of organomineral fertilizers on common bean yield. The experiment was carried out in a greenhouse at the Federal University of Uberlândia. A randomized complete block design was used in the $2 \times 4+2$ factorial scheme corresponding to two organic sources (biosolids and filter cake) and four doses of pelletized organomineral fertilizer (50, 75, 100 and $125 \%$ of the recommendation for common bean, plus two additional treatments without fertilization and fertilization with mineral fertilizer). The plant height and stem diameter were evaluated at 30 days after sowing (DAS), and an average number of pods plant ${ }^{-1}$ and grains pod ${ }^{-1}$, yield $\left(\mathrm{g}\right.$ plant $\left.{ }^{-1}\right)$, dry mass $(\mathrm{g})$, and mass of 1000 grains $(\mathrm{g})$ at 84 DAS. The organomineral fertilizer based on biosolids fertilizer provides the largest growth with the use of $100 \%$ of the recommended dose, the largest volume of dry mass up to $75 \%$ and the highest yield at $50 \%$. The organomineral fertilizer based on filter cake increased dry mass volume. The organomineral fertilizers evaluated have the potential to substitute exclusively mineral fertilization in the common bean crop.
\end{abstract}

Keywords: Phaseolus vulgaris, phosphorus, sewage sludge, sugarcane residue.

Abbreviations: DAS_day after sowing.

Introduction

Present in the Brazilian population diet for being an excellent source of protein, carbohydrates, vitamins, and minerals, the bean is one of the crops with great economic and social importance. The bean has a short cycle in its culture and requires its nutrients to be readily available during its development to ensure productivity (Almeida \& Soratto, 2014). Because of this, studies of fertilization strategies that ensure a better availability of nutrients along the crop cycle are of great importance.

Sewage sludge is a little used waste source of organic matter. Because it is rich in organic matter and mineral nutrients, especially nitrogen and phosphorus, sludge can be harnessed in agricultural areas as a fertilizer or as a soil conditioner, after being properly treated (Lemainski \& Silva, 2006). However, its use is still questioned in Brazil, due to problems related to environmental and human health. Despite this, composting is considered a good alternative for the treatment of sewage sludge with an agronomic purpose since it allows the satisfactory control of pathogenic microorganisms resulting in agricultural raw materials of good quality (Backes et al., 2013). Organomineral fertilizers can be produced with the desired formulation of $\mathrm{N}, \mathrm{P}, \mathrm{K}$ and micronutrients combined with organic sources and mineral sources.
The organic fraction of the organomineral fertilizers can be obtained from other sources such as filter cake which has a high content of organic matter, phosphorus, calcium and potassium (Vazquez et al., 2015). Studies report the versatility of these residues to be used as a constituent part of the substrate for seedlings of fruit species and forestry (Trigueiro \& Guerrini, 2003). Oliveira (2016) found that the organic fertilizer biofertilizers on the basis of sewage sludge was efficient for the sorghum crop. However, studies that verify the potential of biosolids as part of the organic matter of biofertilizers are still at the initial stages. Silva (2017) concluded that biofertilizers formulated with sewage sludge and filter cake can replace the mineral fertilizer nitrogen of the soybean crop, with an increase in plant growth parameters. Quantitative changes in peroxidase, catalase and urease activity, in addition to lipid peroxidation, arise out of the use of biofertilizers.

Magela (2017) emphasizes that in maize crop the use of fertilizer based on biosolids led to increased green mass of aerial parts using the source with filter cake, regardless of the applied dose. The biofertilizers formed the basis of biosolids having the potential to be used for the total or partial supply of nutrients in replacing the mineral fertilization and provided results similar or superior to soil chemical characteristics and growth characteristics of corn. 
The objective of this research was to evaluate the efficiency of organic matter sources and levels of fertilization in the composition of organic fertilizers for common bean fertilization.

\section{Results and discussion}

The use of organomineral fertilizer formulated with biosolids at a dose of $100 \%$ promoted an increase in the average height of bean plants ( $p \leq 0.05$ ) of $66.8 \%$ compared to the control and $44.38 \%$ when compared to mineral fertilizer (Table 1).

The biosolids at doses of 50 and $75 \%$ and the filter cake at doses of 100 and $125 \%$ provided an increase $(p \leq 0.05)$ in the dry mass of aerial part of bean in relation to the control, with increments of approximately $48.8 \%, 51.5 \%, 46.4 \%$ and $48.8 \%$, respectively (Table 2 ).

The use of biosolids at a dose of $50 \%$ promoted an increase in the yield of common bean in relation to mineral fertilization and control, $67 \%$ and $100 \%$, respectively ( $\mathrm{p} \leq 0.05 \%$ ) (Table 2).

There were no differences in the other treatments ( $p \leq 0.05$ ), where neither biosolid nor filter cake was used as source of organomineral fertilizers for any of the analyzed variables: diameter, height, number of pods, number of grains, dry mass of aerial part, weight of 1000 grains and yield, in relation to the control and treatment in which we used mineral fertilization (Table 1 and 2).

In the treatment with $50 \%$ of the recommended dose it was verified that the treatment in which the biosolid was used obtained $22.8 \%$ more of weight of 1000 grains in relation to the fertilizer with filter cake. For the other doses, no differences $(p \leq 0.05)$ were found between the sources (Table 1).

The organic matter is rich in humic substances that release negative charges may decrease $\mathrm{P}$ adsorption by $\mathrm{Fe}$ and $\mathrm{Al}$ oxides, and thus offer the organic matter to the plants. This nutrient is part of several biochemical reactions of plants and is a component of the ATP molecule, essential for photosynthetic activity (Silva et al., 2011). Humic substances may be related to the greater growth of plants in the treatments in which organomineral fertilizers were used and are essential for the filling and grain yield of the common bean.

For the fertilizer produced with biosolids, analysis of the variation of shoot weight, weight of 1000 grains, number of pods per plant, and production showed that except for dry weight of aerial part, where the highest value was observed for the level of fertilization at $84.2 \%$ of the recommendation, the $50 \%$ recommendation level resulted in the highest values (Figure 1A, 1B, 1C and 1D).

When the variables that were influenced by biosolids were examined together it was noted that with the increase of the dose there was also an increase in plant height up to $84.2 \%$ of phosphorus, but there was a reduction in the number of pods, the weight of a thousand grains, and yield per plant of bean. This result may be related to the excessive growth of the plant (etiolation) and thus to the lodging of plants which reduces solar radiation interception. This reduces the photosynthetic process of the plant and consequently its production (Figure 1A, 1B, 1C and $1 D$ ). In the literature, some authors have observed that a reduction in the apical growth of plants increased the branch, and consequently increased the number of pods per plant, culminating in higher grain yield (Soratto et al., 2015), due to the better distribution of dry mass (DM) of the branches to the grains (Gitti et al., 2012).

In the yield per plant, it was verified that the biosolids promoted an increase of $46.4 \%$ in relation to the use of filter cake, at a dose of $50 \%$. For the other doses there were no significant differences between the sources of organomineral fertilizer (Table 4), which may be related to the source of $\mathrm{N}, \mathrm{P}$ and $\mathrm{S}$ due to mineralization and decomposition of organic matter. These are essential nutrients in the photosynthesis process that is responsible for the production of essential elements in the development of the plant.

The $\mathrm{C} / \mathrm{N}$ ratio is another factor that weighs in favor of biosolids as an organic source and may be related to the results obtained as it is a determinant in the processes of decomposition and $\mathrm{N}$ mineralization and availability to the plant (Pereira et al., 2015). Giacomini et al. (2003) observed that if the $\mathrm{C} / \mathrm{N}$ ratio is between 25 to 30 then it will have a balance between the process of mineralization and immobilization, thus slowly freeing $\mathrm{N}$ and thus reduces the leaching and providing more $\mathrm{N}$ for the plant. In the present study, the ratio was 28 for the organic source of sewage sludge (Table 4), which corroborates with the assumption.

The use of organomineral fertilizer from the filter cake has promoted an increase in the dry mass of the aerial part of the bean which fits in the linear model, in which the maximum dose studied at $125 \%$ was $5.55 \mathrm{~g}$. For weight of 1000 grains and number of pods per plant, the most appropriate model was the feces model. Using the organomineral fertilizer on the basis of filter cake, it was found that the dose of $103.9 \%$ promoted a mass of $254.83 \mathrm{~g}$ and $87.5 \%$ was 6.07 pods per bean (Figure 2A, 2B and 2C). For productivity and weight of 1000 grains, regardless of the source of organic matter used, the increase in the dose promoted a decrease in the observed values.

Analyzing together the variables weight of 1000 grains and number of pods, it was observed that even without having an increase in the number of pods, the grain filling was higher in treatments in which were used organomineral fertilizer based on filter cake (Table 4). Phosphorus is an important nutrient for plant processes, such as photosynthesis, because it is directly related to the capture and conversion of solar energy, and this organic source has high levels of organic phosphorus. At higher doses of $P$, losses occurred in the common bean yield. However, due to a significant reduction in performance, we can confirm there is a synergetic interaction of $P$ and $N$ (Silva et al., 2011), since the $\mathrm{N}$ is directly connected to the metabolic processes of the plant and consequently the yield. However, no damage was observed on plant development and yield when compared to mineral fertilization, since both an excess or a deficiency in a nutrient may promote damage to the plant (Leal \& Prado, 2008). This occurs because a nutrient in abnormal levels may impair the development of the plant, causing a nutritional stress.

Nitrogen is responsible for the growth and development of plants, and consequently to an increase in yield, and it is present in molecules and proteins of chlorophyll and is directly associated with the photosynthetic activity and the rate of translocation of assimilates (Boussadia et al., 2011, Santos et al. 2016). Analyzing together the variables related 
Table 1. The diameter of the plants $(\mathrm{cm})$, plant height $(\mathrm{cm})$, number of pods per plant of common bean, in function of the biofertilizer application of fertilizers and mineral fertilizer.

\begin{tabular}{|c|c|c|c|c|c|c|}
\hline \multirow{3}{*}{ Dose (\%) } & \multicolumn{2}{|l|}{ Diameter } & \multicolumn{2}{|c|}{ Plant height } & \multicolumn{2}{|c|}{ Number of pods } \\
\hline & \multicolumn{6}{|c|}{ Organomineral Fertilizer } \\
\hline & Biosolids & Filter cake & Biosolids & Filter cake & Biosolids & Filter cake \\
\hline 50 & 4.41 & 4.32 & 44.37 & 43.20 & 8.00 & 7.19 \\
\hline 75 & 4.07 & 4.11 & 48.86 & 41.99 & 6.63 & 6.44 \\
\hline 100 & 4.39 & 4.04 & $53.51 *$ & 47.64 & 6.94 & 6.69 \\
\hline 125 & 4.13 & 4.32 & 38.14 & 40.82 & 6.26 & 7.81 \\
\hline Average & $4.25 \mathrm{a}$ & $4.19 \mathrm{a}$ & $46.22 \mathrm{a}$ & $43.41 \mathrm{a}$ & $6.96 \mathrm{a}$ & $7.03 \mathrm{a}$ \\
\hline Mineral Fertilizer & 4.21 & & 37.06 & & 6.19 & \\
\hline Control & 4.04 & & 32.07 & & 5.56 & \\
\hline DMS Dunnett & 0.74 & & 18.32 & & 2.44 & \\
\hline DMS Source & 0.24 & & 6.79 & & 0.88 & \\
\hline
\end{tabular}

Tukey test at 0.05 . Biosolids: organomineral fertilizer based on sewage sludge; Filter cake: organomineral fertilizer to the base of filter cake.
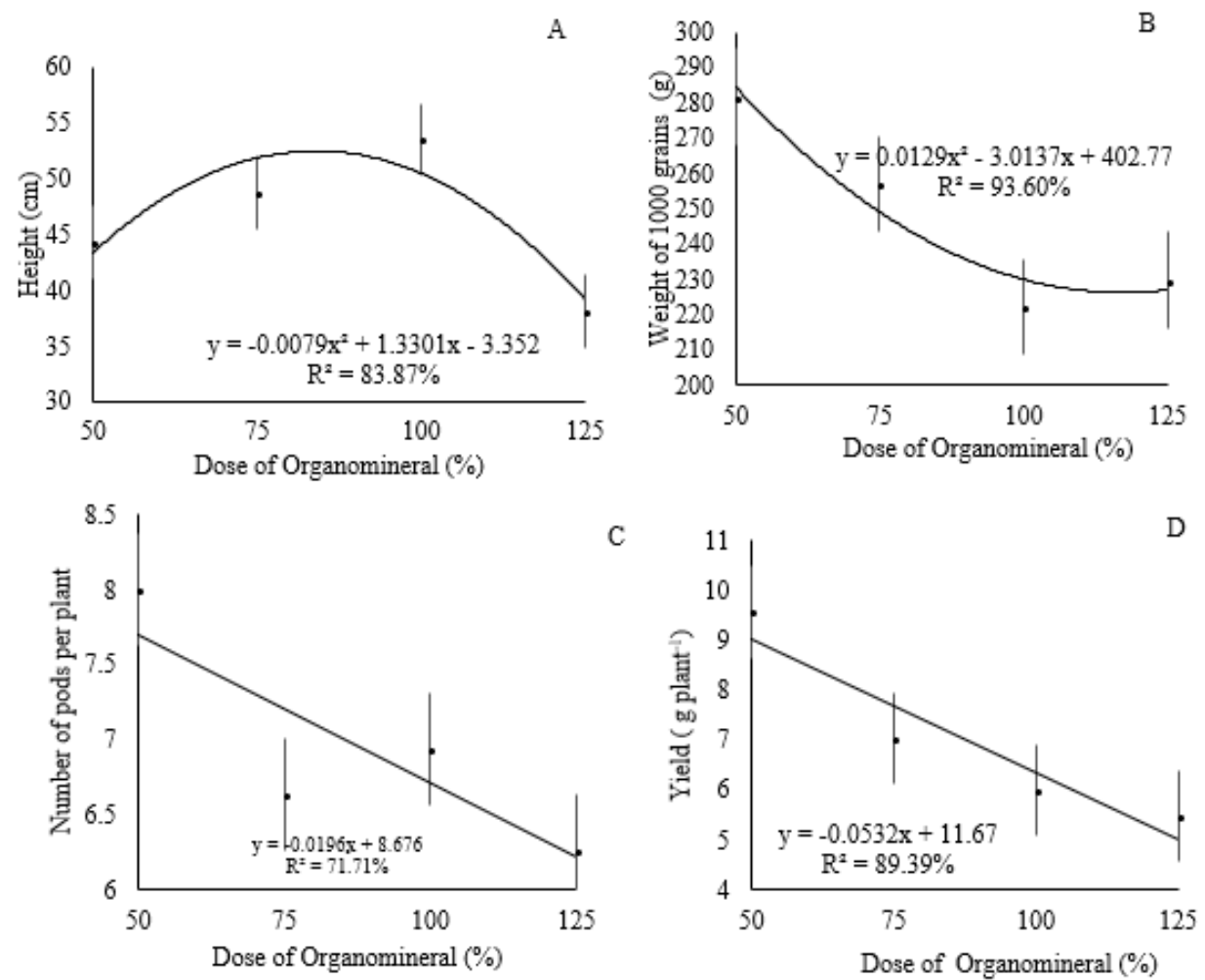

Fig 1. Plant height $(\mathrm{cm})(\mathrm{A})$, number of pods per plant $(B)$, weight of 1000 grains $(\mathrm{g})(\mathrm{C})$ and yield per plant (g) (D), bean cultivar Pérola, depending on the application of dose of organomineral fertilizer on the basis of sewage sludge.

Table 2. Number of grains per pod, dry mass (DM) of aerial part (g), weight of 1000 grains (g), yield (g plant ${ }^{-1}$ ) of common bean, in function of the application of fertilizers organomineral and mineral fertilizer.

\begin{tabular}{|c|c|c|c|c|c|c|c|c|}
\hline \multirow{3}{*}{ Dose (\%) } & \multirow{2}{*}{\multicolumn{2}{|c|}{$\begin{array}{l}\text { Number of grains } \\
\text { Organomineral Fertilizer }\end{array}$}} & \multicolumn{2}{|l|}{ DM root } & \multicolumn{2}{|c|}{ Weight of 1000 grains } & \multicolumn{2}{|l|}{ Yield } \\
\hline & & & & & & & & \\
\hline & Biosolids & Filter cake & Biosolids & Filter cake & Biosolids & Filter cake & Biosolids & Filter cake \\
\hline 50 & 3.98 & 4.04 & $5.55^{*}$ & 4.59 & $281.58 \mathrm{a}$ & 229.27 b & $9.56 a^{\circ *}$ & $6.53 \mathrm{~b}$ \\
\hline 75 & 4.05 & 4.26 & $5.65^{*}$ & 5.14 & $257.09 \mathrm{a}$ & $237.25 \mathrm{a}$ & $7.03 \mathrm{a}$ & $6.58 \mathrm{a}$ \\
\hline 100 & 3.87 & 4.00 & 5.16 & $5.46^{*}$ & $222.05 \mathrm{a}$ & $264.36 \mathrm{a}$ & $6.00 \mathrm{a}$ & $7.63 \mathrm{a}$ \\
\hline 125 & 3.73 & 3.91 & 4.71 & $5.55^{*}$ & $229.72 \mathrm{a}$ & $247.65 \mathrm{a}$ & $5.47 \mathrm{a}$ & $7.28 \mathrm{a}$ \\
\hline Average & $3.91 \mathrm{a}$ & $4.05 \mathrm{a}$ & $5.27 \mathrm{a}$ & $5.18 \mathrm{a}$ & $247.72 \mathrm{a}$ & $244.63 \mathrm{a}$ & $7.02 \mathrm{a}$ & $7.00 \mathrm{a}$ \\
\hline Mineral Fertilizer & 3.91 & & 4.77 & & 236.00 & & 5.72 & \\
\hline Control & 4.01 & & 3.73 & & 236.57 & & 4.76 & \\
\hline DMS Dunnett & 0.84 & & 1.72 & & 59.21 & & 3.11 & \\
\hline DMS Source & 0.32 & & 0.59 & & 22.28 & & 1.13 & \\
\hline
\end{tabular}

and : different by 

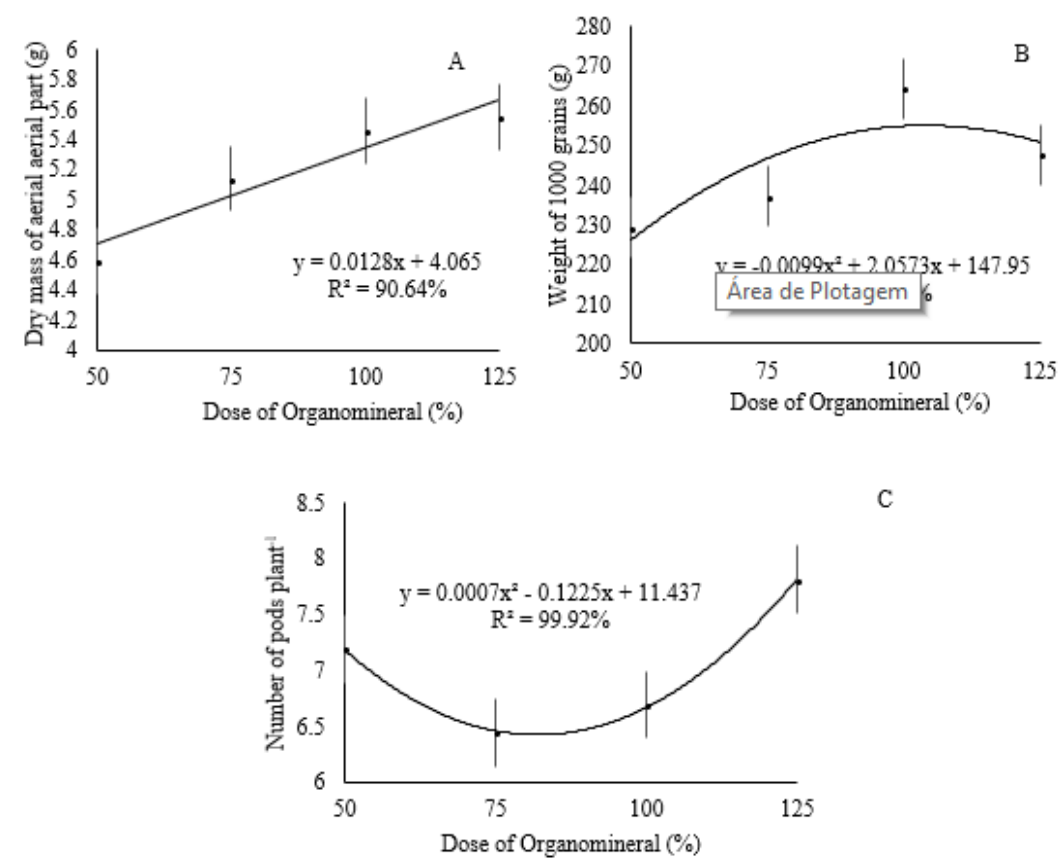

Fig 2. Dry mass of aerial part in grams (A), weight of 1000 grains in grams (B) and number of pods per plant (C), bean cultivar Pérola, depending on the application of dose of organomineral fertilizer on the basis of filter cake.

Table 3. Chemical characterization of the sample of the Oxisol used in the experiment.

\begin{tabular}{|c|c|c|c|c|c|c|c|c|c|c|c|c|}
\hline & Pmeh & $\mathrm{K}^{+1}$ & $\mathrm{Ca}^{+2}$ & $\mathrm{Mg}^{+2}$ & $\mathrm{Al}^{+3}$ & $\mathrm{H}+\mathrm{Al}$ & SB & $\mathrm{t}$ & $T$ & $\mathrm{~V}$ & $\mathrm{~m}$ & M.O. C.O \\
\hline $\mathrm{pH}_{2} \mathrm{O}$ & $\mathrm{mg} \mathrm{dm^{-3 }}$ & ----- & ----- & - & $\mathrm{mol}_{\mathrm{c}}$ & -3------ & - & -- & & $----\%$ & -- & ---dag kg ${ }^{-1}--$ \\
\hline 6.2 & 2.3 & 0.31 & 2.3 & 0.8 & 0.0 & 2.8 & 3.41 & 3.41 & 6.21 & 55.0 & 0.0 & 2.7 \\
\hline
\end{tabular}

$\mathrm{P}=$ Method Mehlich 1, P, K, Na $=\left[\mathrm{HCl} 0.05 \mathrm{~mol}^{-1}+\mathrm{H}_{2} \mathrm{SO}_{4} 0.0125 \mathrm{~mol} \mathrm{~L}^{-1}\right] \mathrm{S}-\mathrm{SO}_{4}=$ Monobácico Calcium Phosphate $\left[0.01 \mathrm{~mol} \mathrm{~L}^{-1}\right], \mathrm{Ca}, \mathrm{Mg}, \mathrm{Al}=\left[\mathrm{KCL} 1 \mathrm{~mol} \mathrm{~L}^{-1}\right] / \mathrm{H}+\mathrm{Al}=[\mathrm{SMP}$ buffer solution at $\mathrm{pH}$ 7.5], M.O. = Colorimetric Method, $\mathrm{S} . \mathrm{B}=$ Sum of base, $\mathrm{V}=$ Base saturation; $\mathrm{T}=\mathrm{CTC} \mathrm{pH} 7.0$;
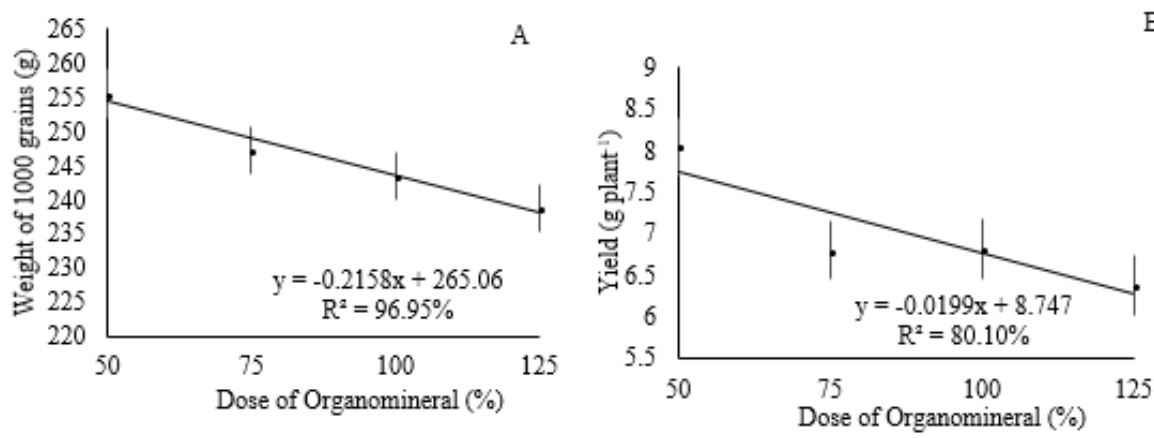

Fig 3. Weight of 1000 grains in grams (A) and plant yield in grains (B), bean cultivar Pérola, depending on the application of dose of fertilizer organomineral regardless of the source used.

Table 4. Chemical attributes of biosolids treated.

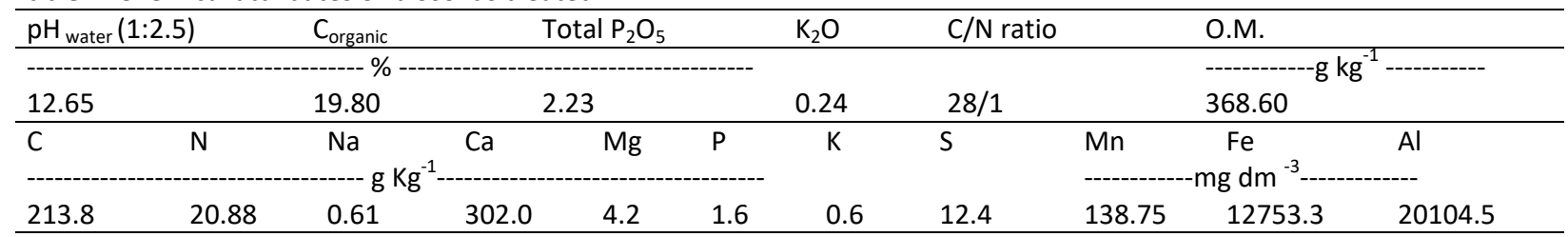

Characterized according to the methodology of Santos et al. (2013). Corganic: total organic carbon. O.M.: Organic matter. 
Table 5. Chemical attributes of filter cake.

\begin{tabular}{llllll}
\hline $\mathrm{pH}_{\text {water }}(1: 2.5)$ & $\mathrm{C}_{\text {organic }}$ & Total $\mathrm{N}$ & Total $\mathrm{P}_{2} \mathrm{O}_{5}$ & $\mathrm{~K}_{2} \mathrm{O}$ & $\mathrm{C} / \mathrm{N}$ ratio \\
\hline & -23.49 & 0.61 & 0.95 & 0.30 & $13.72 / 1$ \\
\hline
\end{tabular}

to production, number of pods, number of grains, number of weight of thousand grains and efficiency in the use of organomineral fertilizer on the basis of biosolids at lower doses, it was found that these factors were higher than in the mineral fertilizer, without even promoting differences $(p>0.05)$, and demonstrating that these low doses of $P$ promote antagonism between these nutrients.

\section{Materials and methods}

\section{Description of the environment}

The experiment was conducted in a greenhouse at Capim Branco Farm, belonging to the Federal University of Uberlândia, Uberlândia, Minas Gerais, located at coordinates $18^{\circ} 52^{\prime} 55^{\prime} 66 \mathrm{~S}$ and $48^{\circ} 20^{\prime} 28^{\prime} 21$, at an altitude of $805 \mathrm{~m}$, between the period of July and September, 2015. The climate of the region is classified by the method of Köppen (1948), as Aw, tropical hot and humid, with cold and dry winter. The average annual temperature is $21.5^{\circ} \mathrm{C}$ with an average annual rainfall of $1479 \mathrm{~mm}$ (Rolim et al., 2007).

It was used a Red-Yellow Latosol (Oxisol), according to the Brazilian System of Soil Classification (V> 50\%) (Santos et al., 2013), which was submitted to chemical analysis (Table 3 ) in the $0-20 \mathrm{~cm}$ layer, according to Donagema et al. (2011). It was verified that there was no need to apply limestone for $\mathrm{pH}$ correction, due to its presence in the ideal range for the culture. The biosolid used as an organic part of the organomineral fertilizer was obtained from the sewage sludge collected at the DMAE treatment station located in the city of Uberlândia, MG. For the elimination of pathogens and reduction of the moisture content, the sewage sludge underwent the solarization process combined with a mixture of $30 \%$ hydrated lime on a dry basis (Alves Filho et al., 2014). After treatment and drying, the biosolid was analyzed chemically in LABAS-UFU and used in the production of organomineral fertilizer by the company Geociclo. The filter cake used for organomineral fertilizer production was provided by Vale do Tijuco, and the chemical attributes of the two sources of organic matter are shown in the tables (4 and 5).

\section{Factorial scheme and statistical design}

The experiment was conducted in a randomized block design with four replicates, in a $2 \times 4+2$ factorial scheme, corresponding to two organic sources for formulation of organomineral fertilizer (biosolid and filter cake), four levels of fertilization with pelletized organomineral fertilizer, 50\%, $75 \%, 100 \%$ and $125 \%$ of the recommendation for the bean crop (Alvarez et al, 1999) and two additional treatments, being mineral fertilizer ( $100 \%$ of the recommended dose) and control (without fertilization). Organomineral fertilizers used corresponded to the formulations 5-17-10, with $0.1 \%$ of boron, $3 \%$ of silicon and $8 \%$ of Total Organic Carbon, each batch consisting of two vessels with a capacity of 5 liters of soil, with dimensions of $20 \mathrm{~cm}$ of height and $20 \mathrm{~cm}$ of superior diameter and $17 \mathrm{~cm}$ of inferior diameter.

\section{Conduction of the experiment and evaluated parameters}

The sowing was done at a depth of $4 \mathrm{~cm}$, with four seeds per pot and then thinning at 20 days, when two plants were left per pot.

The cultivar used was the Pearl of the Carioca group, which has a cycle with an average duration of 90 days. The first cover fertilization was performed 20 days after sowing, with $0.168 \mathrm{~g}$ of urea per pot, corresponding to $30 \mathrm{~kg} \mathrm{ha}$ of nitrogen $(\mathrm{N})$ in all treatments. At 30 days after sowing the second cover fertilizer was with the same amount of $\mathrm{N}$ as the first. Measurements of plant height and stem diameter were performed at 30 days after planting.

Harvesting was performed 84 days after sowing, when the grains had a mean moisture content of $10 \%$. At the time of harvesting, the aerial part of the plant was cut at the height of the colon, when the pods were separated. The pods were counted to determine the average number of pods per plant and the beans were counted for determination of an average number of grains per pod. The grains were baked at $\pm 103^{\circ} \mathrm{C}$ in two replicates and then weighed on a precision scale for determination of moisture content and correction for $13 \%$ of 1000 grains and yield. The aerial part was taken to a furnace at $65^{\circ} \mathrm{C}$ and after weighing constant weight on a precision scale to determine the dry weight of the aerial part of the plant.

To compare the averages, the Tukey's test was used at 5\% probability and for the analysis of the fertilizer doses for biofertilizer the polynomial regression test was used with the aid of the SISVAR program (Ferreira, 2011). For the comparison of additional treatments with other treatments, the Dunnet test ( $p$ 0.05) was used in the statistical program Assistat (Silva \& Azevedo, 2016).

\section{Conclusion}

The organomineral fertilizer on the basis of biosolids provides greater growth in a dose of $100 \%$, a larger volume of dry mass of aerial part at doses of 50 and $75 \%$ of $P$ and a greater yield in the dose of $50 \%$ of $\mathrm{P}$ by bean plants.

The organomineral fertilizer on the basis of filter cake at doses of 100 and $125 \%$ of $P$ provides greater volume of dry mass of aerial part of bean. The organomineral fertilizer on the basis of biosolids provides better results in the mass of one thousand grains and yield per bean plants in relation to the use of biofertilizers based on filter cake. The recommended dose for the organomineral fertilizer is $50 \%$ of $P$ for the source of biosolids and $100 \%$ of $P$ for the source of filter cake for the common bean crop. 


\section{Acknowledgements}

The authors thank the Agrarian Science Institute (ICIAG UFU) for financial support.

\section{References}

Almeida AQ de Soratto RP (2014). Teor e acúmulo de nutrientes no feijoeiro em função da aplicação de bioestimulante. Semin Ciênc Agrár, 35 (4): 2259-2272.

Alvarez VVH., Novais RF, Barros NF, Cantarutti RB, Lopes AS (1999) Interpretação dos resultados das análises de solo. In: Ribeiro AC, Guimarães PTG, Alvarez VVH. (Eds.). Recomendações para o uso de corretivos e fertilizantes em Minas Gerais - 5a Aproximação. Viçosa, Comissão de Fertilizantes do Solo do Estado de Minas Gerais. 30-38.

Alves Filho A (2014) Of sewage sludge anaerobic for agricultural purposes. Uberlândia: Universidade Federal de Uberlândia, 2014. Dissertation, $79 \mathrm{f}$.

Boussadia O, Steppe K, Zgallai H, El Hadj SB, Braham M, Lemeur R, Van Labeke M C (2011). Nondestructive determination of nitrogen and chlorophyll content in olive tree leaves and the relation with photosynthesis and fluorescence parameters. Photosynthetica, 49 (1): 149153.

Donagema GK., de Campos DB, Calderano SB, Teixeira WG, Viana JM. (2011). Manual de métodos de análise de solo. Embrapa Solos-Documentos (INFOTECA-E).

Ferreira DF (2011). Sisvar: a computer statistical analysis system. Ciênc Aagrotec, 35 (6): 1039-1042.

Giacomini SJ, Aita C, Vendrscolo ERO, Cubilla M, Nicoloso RS, Fries MR (2003). Matéria seca, relação $C / N$ e acúmulo de nitrogênio, fósforo e potássio em misturas de plantas de cobertura do solo. Rev Bras Ciênc Solo, 27 (2): 325-334.

Gitti DC, Arf O, Buzetti S, Ferreira MMR, Kappes C, Kaneko FH, Rodrigues RAF (2012). Aplicação de paclobutrazol e doses de nitrogênio em feijão de inverno cultivado em sistema plantio direto. Sci Agrar Parana, 11 (3): 35-46.

Leal RM, Prado R de M (2008) Desordens nutricionais no feijoeiro por deficiência de macronutrientes, boro e zinco. Rev Bras Ciênc Agrár, 3 (4): 301-306.

Lemainski J, Silva JE (2006). Avaliação agronômica e econômica da aplicação de biossólido na produção de soja. Pesqui Agropecu Bras, 41 (10): 1477-1484.

Magela MLM (2017) Fontes de matéria orgânica na composição de fertilizantes organominerais peletizados na cultura do milho. Uberlândia: Universidade Federal de Uberlândia, 2014. Dissertation, $83 \mathrm{f}$.

Nogueira TA, Sampaio RA, Fonseca IM, Ferreira CS, Santos SE, Ferreira LC, Fernandes LA (2007). Metais pesados e patógenos em milho e feijão caupi consorciados, adubados com lodo de esgoto. Rev Bras Eng Agric Amb, 11 (3): 331338.
Oliveira DP (2016) Fontes de matéria orgânica para a formulação de fertilizantes organominerais peletizados no desenvolvimento da cultura do sorgo. Uberlândia: Universidade Federal de Uberlândia, 2014. Dissertation. 46 f.

Pereira RF, De Lima AS, Maia Filho FDCF, Cavalcante SN, Dos Santos JGR, Andrade R (2013). Produção de feijão vigna sob adubação orgânica em ambiente semiárido. Agropecu Cient Semiárido, 9 (2): 27-32.

Pereira LB, Arf O, Belmiro Dos Santos NC, Zini De Oliveira AE, Kenji Komuro L (2015). Manejo da adubação na cultura do feijão em sistema de produção orgânico. Pesqui Agropecu Trop, 45 (1): 29-38.

Rolim G de S, Paes de Camargo MBP, Lania DG, De Moraes JFL (2007). Classificação climática de Köppen e de Thornthwaite e sua aplicabilidade na determinação de zonas agroclimáticas para 0 estado de São Paulo. Bragantia, 66 (4): 711-720

Santos HG dos, Jacomine PKT, Anjos LHC dos, Oliveira VA de; Lumbreras JF, Coelho MR, Almeida JA de, Cunha TJF, Oliveira JB de (2013) Sistema brasileiro de classificação de solos. 3.ed. rev. e ampl. Brasília: Embrapa. 353p.

Santos SMC, Antonangelo JA, Deus ACF, Fernandes DM (2016) Perdas de amônia por volatilização em resposta a adubação nitrogenada do feijoeiro. R Agr Neot, 3 (1): 1620.

Scherer EE, Spagnollo E (2014). Propriedades químicas do solo e produtividade de milho e feijão no sistema orgânico com uso de diferentes fontes de adubo. Ver Agropecu Catarin, 27 (1): 80-85.

Silva FLDA, De Lacerda CF, De Sousa GG, Neves AL, Da Silva GL, Sousa CH (2011). Interação entre salinidade e biofertilizante bovino na cultura do feijão-de-corda. Ver Bras Eng Agríc Amb, 15(4): 383-390.

Silva FAS, De Azevedo CAV (2016). The Assistat Software Version 7.7 and its use in the analysis of experimental data. Afr J Agr Res, 11(39): 3733-3740.

Silva JIC, Pereira FR, Cruz SC, Pereira MRR, Freitag EE, Araújo HB, Villas Bôas RL (2009). Uso de estimulantes de crescimento radicular associado a doses de fósforo na cultura do feijoeiro. Agrarian, 2(5), 47-62.

Silva Lopes AD, Queiroz De Oliveira G, Nilce Souto Filho $S$, Goes RJ, Camacho MA (2011). Manejo de irrigação e nitrogênio no feijoeiro comum cultivado em sistema plantio direto. Rev Ciênc Agron, 42(1): 51-56.

Soratto RP, Souza-Schlick GD de, Fernandes AM, Oliveira LFFA de (2015). Crescimento e produtividade de duas cultivares de feijão em função de doses de ácido 2,3,5triiodobenzoico. Cienc. Rural, 45 (12): 2181-2186

Trigueiro R de M, Guerrini IA (2003) Uso de biossólido como substrato para produção de mudas de eucalipto. Sci For, 64, $150-162$.

Vazquez GH, Bortolin R, Vanzela LS, Dos SB, Bonini C, Neto ABB (2015). Uso de fertilizante organofosfatado e torta de filtro em cana-planta/use of organophosphated fertilizer and filtercake in plant-cane. R Bras Eng Bios, 9 (1): 53-64. 